\title{
Recombinant interleukin-1 $\beta$ activates the hypothalamic-pituitary-interrenal axis in rainbow trout, Oncorhynchus mykiss
}

\author{
J W Holland, T G Pottinger ${ }^{1}$ and C J Secombes \\ Department of Zoology, University of Aberdeen, Aberdeen AB24 2TZ, UK \\ ${ }^{1}$ NERC Centre for Ecology and Hydrology, The Ferry House, Far Sawrey, Ambleside, Cumbria LA22 OLP, UK \\ (Requests for offprints should be addressed to C J Secombes; Email: c.secombes@abdn.ac.uk)
}

\begin{abstract}
The present study provides the first direct evidence that implicates fish cytokines as the effector molecules by which the immune system signals the neuroendocrine system and activates the hypothalamic-pituitary-interrenal stress axis. I.p. injections of trout recombinant interleukin-1 $\beta$ (rIL-1 $\beta$ ) or E. coli lipopolysaccharide (LPS), at concentrations known to induce immune/inflammatory responses in vivo $(0 \cdot 1-0.6 \mathrm{nmol} / \mathrm{kg}$ and $1.3 \mathrm{mg} / \mathrm{kg}$ respectively), significantly elevated plasma cortisol levels in a dose- and/or time-dependent manner. However, in contrast to general stress responses in fish, under the conditions employed in this study, no specific treatment effects on plasma glucose levels could be demonstrated. The trout IL-1 $\beta$ peptides (P1 and P3), which are homologous to
\end{abstract}

receptor-binding sequences of human IL-1 $\beta$, failed to influence the prevailing cortisol concentration even though an equivalent dose has been found to have immunostimulatory properties in vivo. Blockade of endogenous ACTH release by administration of the synthetic glucocorticoid dexamethasone prevented the rIL$1 \beta /$ LPS-mediated elevation of plasma cortisol, suggesting that IL-1 $\beta$ and LPS modulate cortisol secretion via effects at the level of the hypothalamic-pituitary axis. These data indicate that, with respect to IL-1 $\beta$, cytokine signalling between the immune and neuroendocrine systems in mammals appears to be conserved in lower vertebrates.

Journal of Endocrinology (2002) 175, 261-267

\section{Introduction}

Proinflammatory cytokines in mammals, particularly interleukin (IL)-1 $\beta$, have been identified as the effector molecules by which the immune system signals the hypothalamic-pituitary-adrenal (HPA) axis, primarily with respect to the stimulated release of hypothalamic corticotrophin-releasing hormone $(\mathrm{CRH})$ (Shintani et al. 1995, Turnbull \& Rivier 1999). Indeed, the systemic and central nervous system (CNS) generation of IL-1 $\beta$ in response to endotoxin treatment and to physical or psychological stressors is known to contribute towards the associated HPA secretory activity (Shintani et al. 1995, Turnbull \& Rivier 1999). However, the efficacy of cytokine action within the HPA axis depends on the prevailing glucocorticoid concentration (Buckingham et al. 1994, 1996), since the HPA axis is subjected to feedback control by glucocorticoids at the hypothalamic-pituitary level (Sapolsky et al. 2000). In addition to the effects on the HPA axis, there is also evidence that peripherally administered IL-1 $\beta$ may influence glucose metabolism, causing a marked and prolonged hypoglycaemic response (Rey \& Besedovsky 1987).
In fish, research into the cross-talk between the immune and neuroendocrine systems has focused on the modulation of immune and inflammatory processes by hormones and the expression of their receptors in fish leucocytes, particularly with respect to the interrenal glucocorticoid, cortisol (Wendelaar-Bonga 1997, Weyts et al. 1999). However, in contrast to understanding the effects of fish hormones, progress in examining the impact of immune-derived signals on the neuroendocrine system has been greatly hampered by the absence of cloned fish cytokine genes and the production of their recombinant proteins, although the cytokine-inducing mitogen lipopolysaccharide (LPS) is known to stimulate hypothalamic-pituitary-interrenal (HPI) secretory activity in fish (Balm 1997).

Recently, the IL-1 $\beta$ gene sequence in both rainbow trout (Zou et al. 1999a,b) and carp (Fujiki et al. 2000) was elucidated, thus enabling the production of functional fish IL-1 $\beta$ recombinant proteins. Since then, the gene has been cloned in a number of other fish including the first sequence from a cartilaginous species (Secombes et al. 2001, Bird et al. 2002). In vitro and in vivo studies with trout recombinant IL-1 $\beta$ (rIL-1 $\beta$ ), to date, have 
demonstrated the potency of this molecule in inducing a range of immune genes (e.g. IL- $\beta$, cyclooxygenase- 2 and MHC class II $\beta$ chain) and stimulating phagocytosis, leucocyte bactericidal activity and leucocyte migration (Hong et al. 2001, Peddie et al. 2001, Hong 2002). Furthermore, short IL-1 $\beta$ peptides (P1 and P3) have been constructed to correspond to areas within the trout rIL-1 $\beta$ molecule that are predicted to interact with the signaltransducing binding site of the IL-1 receptor (Secombes et al. 1998). In a similar manner to the whole rIL-1 $\beta$ molecule, the peptide $\mathrm{P} 3$ has been found to have profound immunostimulatory properties both in vitro and in vivo, with evidence of synergy occurring between P1 and P3 (Peddie et al. 2001, 2002, Hong 2002, Peddie 2002).

In view of the lack of knowledge regarding the role of cytokines in the neuroendocrine stress response of fish, the present work was undertaken to investigate the in vivo activity of administered trout rIL-1 $\beta$, IL-1 $\beta$ peptides (P1 and P3) and LPS by measuring plasma cortisol and glucose levels in fish with both intact and dexamethasone (DEX)blocked HPI axes.

\section{Materials and Methods}

\section{Fish and reagents}

A mixed-sex population of sexually immature rainbow trout Oncorhynchus mykiss (100-300 g), reared at the Centre for Ecology and Hydrology, Windermere, Cumbria, UK, was maintained in 10001 outdoor tanks supplied with a constant flow of lake water $(251 / \mathrm{min})$ at mean temperatures of $13.9 \pm 0.2{ }^{\circ} \mathrm{C}$ (mean \pm s.E.; initial time-course experiment) and $14.8 \pm 0.1{ }^{\circ} \mathrm{C}$ (mean \pm S.E.; DEX-block study). The fish were fed three times weekly (Trouw Standard Expanded 40, Trouw Aquaculture, Wincham, UK) at the manufacturers' recommended rate. Feeding was discontinued during the experiments. The synthetic IL-1 $\beta$ peptides P1 (YVTPVPIETEAR) and P3 (YRRNTGVDIS), corresponding to a molecular mass of $1.37 \mathrm{kDa}$ (amino acids $146-157$ ) and $1.18 \mathrm{kDa}$ (amino acids 207-216) respectively, were designed and produced as described previously (Peddie et al. 2001). The batches of peptides used have been shown to influence immune gene expression and leucocyte function (Hong 2002, Peddie 2002) at a concentration equivalent to the dose used in this study (see below). $\left[1,2,6,7-{ }^{3} \mathrm{H}\right]$ cortisol $(2 \cdot 22 \mathrm{TBq} / \mathrm{mmol})$ was purchased from Amersham Pharmacia Biotech UK, and cortisol antibody (IgG-F-2) was purchased from Campro Scientific (Veenendaal, The Netherlands). All other reagents were obtained from Sigma unless otherwise stated.

\section{Production of trout $r I L-1 \beta$}

Trout rIL-1 $\beta$ was purified using a modified protocol from the method described by Hong et al. (2001). The six histidine-tagged cDNA sequence encoding the predicted mature IL-1 $\beta$ peptide was cloned into the vector $p Q E 30$ (Invitrogen) and transformed into E. coli cells (JM109; Promega). Clones containing the insert were selected by PCR screening and plasmid DNA was sequenced to confirm that there had been no alteration of the coding domain. Cells from a single colony were cultured in $10 \mathrm{ml}$ LB medium containing ampicillin $(50 \mu \mathrm{g} / \mathrm{ml})$ and shaken (200 r.p.m.) overnight at $37^{\circ} \mathrm{C}$ followed by culture in $500 \mathrm{ml} \mathrm{LB}$ medium for $4 \mathrm{~h}$ at $37^{\circ} \mathrm{C}$. Recombinant protein production was induced following the addition of $1 \mathrm{mM}$ isopropyl- $\beta$-D-thiogalactoside to the cells followed by a further incubation of $4 \mathrm{~h}$ at $37^{\circ} \mathrm{C}$. Cells were harvested and resuspended in $5 \mathrm{ml}$ lysis buffer $(8 \mathrm{M}$ urea, $0.1 \mathrm{M}$ $\mathrm{NaH}_{2} \mathrm{PO}_{4}, 0.01 \mathrm{M}$ Tris- $\mathrm{HCl}, 20 \mathrm{mM}$ imidazole, $\mathrm{pH} 8 \cdot 0$ ), and mixed continually for $60 \mathrm{~min}$ at room temperature. The cell lysate was applied to a Ni-nitriloacetic acid column (Qiagen) equilibrated with lysis buffer. Proteins lacking the His tag were eluted using lysis buffer solutions (pH 6.3 and 5.9 successively). The immobilized IL-1 $\beta$ was refolded by washing repeatedly with buffer containing $50 \mathrm{mM}$ Tris- $\mathrm{HCl}, 500 \mathrm{mM} \mathrm{NaCl}, 5 \mathrm{mM} \mathrm{MgCl}, 20 \%$ glycerol and $20 \mathrm{mM}$ imidazole, $\mathrm{pH} 8 \cdot 0$. Bound recombinant protein was eluted using buffer containing $250 \mathrm{mM}$ imidazole.

Protein levels of the flow-through fractions were determined (Bradford 1976) and the size and purity of the eluted protein was confirmed by SDS-PAGE. Eluted fractions exhibited a single protein band with a molecular mass of approximately $20 \mathrm{kDa}$, in agreement with previous studies (Hong et al. 2001, Peddie et al. 2001). Using a Limulus amebocyte lysate kit (Sigma), the LPS levels detected in rIL-1 $\beta$ preparations have been found to be consistently less than $16 \mathrm{ng} / \mathrm{ml}$ and are, therefore, unlikely to interfere with the bioactivity of the rIL- $1 \beta$ preparation since far greater concentrations are needed to induce effects in trout leucocytes (Zou et al. 2000).

\section{I.p. injection of trout $r I L-1 \beta, I L-1 \beta$ peptides and E. coli LPS}

Two weeks prior to the experiment, 64 fish were distributed evenly between eight tanks, containing 5001 water. At the start of the study, fish were removed from each tank in turn, anaesthetized (2-phenoxyethanol, 1:2000 v/v), marked on the ventral surface with alcian blue dye using a Panjet needleless injector (Wright Dental Group, Manchester, UK) for subsequent identification, and injected with one of eight treatments before being returned to their holding tank. Each tank, therefore, contained eight fish each receiving one of eight treatments, thereby ensuring that all treatments were replicated across tanks, avoiding the possibility of unaccounted-for tank effects. In order to minimize the disturbance associated with capture of the fish throughout the study, anaesthetic was injected directly into the incoming water supply to each tank. After a period to allow for mixing, the water supply was shut off 
and the immobilized fish were rapidly removed from the tank using a dipnet. The eight treatments administered to fish by i.p injection in a total volume of $400 \mu$ of vehicle were: (i) trout $\mathrm{rIL}-1 \beta(0 \cdot 1 \mathrm{nmol} / \mathrm{kg})$; (ii) trout $\mathrm{rIL}-1 \beta$ $(0.6 \mathrm{nmol} / \mathrm{kg})$; (iii) IL-1 peptide P1 $(5 \cdot 1 \mu \mathrm{mol} / \mathrm{kg})$; (iv) IL-1 peptide P3 $(5 \cdot 1 \mu \mathrm{mol} / \mathrm{kg})$; (v) LPS (E. Coli 0127:B8, $1.3 \mathrm{mg} / \mathrm{kg}$ ); (vi) IL-1 $\beta$ peptides P1 and P3 evenly mixed and injected at a final dose of $5 \cdot 1 \mu \mathrm{mol} / \mathrm{kg}$ (to test for possible synergistic effects); (vii) recombinant elution buffer (REB, vehicle for rIL-1 $\beta$ ); (viii) PBS (vehicle for LPS and IL-1 $\beta$ peptides). Blood samples from each fish $(\sim 500 \mu \mathrm{l})$ were taken from the cuverian sinus into a heparinized syringe immediately before injection and at 8 , 24, 48 and $72 \mathrm{~h}$ thereafter. Blood was kept on ice until centrifugation and plasma samples were stored at $-20{ }^{\circ} \mathrm{C}$ prior to cortisol and glucose determination.

\section{DEX blockade}

In order to further investigate the interaction of rIL-1 $\beta$ and LPS with the HPI axis in trout, the cortisol agonist DEX was utilized. DEX is a potent cortisol agonist, suppressing the release of adrenocorticotrophic hormone (ACTH) by the pituitary via negative feedback exerted at the hypothalamic/pituitary level. It possesses the additional advantage of failing to cross-react in the cortisol RIA, therefore allowing the determination of endogenous cortisol levels in DEX-treated fish. Thirty-two fish were divided evenly between four tanks as described above. At $24 \mathrm{~h}$ prior to i.p injection with $\mathrm{rIL}-1 \beta(0.6 \mathrm{nmol} / \mathrm{kg})$ or LPS $(1.3 \mathrm{mg} / \mathrm{kg})$, four fish in each tank received DEX $(1 \mathrm{mg} / \mathrm{kg}$ in PBS:ethanol, 3:1; $150 \mu \mathrm{l})$ or vehicle only. Blood samples were collected from the fish at 3,6 and $8 \mathrm{~h}$ after treatment for cortisol and glucose analysis. To confirm that the DEX treatment was effective in blocking the endogenous pituitary/interrenal response to stress, four groups of eight fish from the experimental stock were injected with DEX as described above. At $24 \mathrm{~h}$ after the injection, the fish were transferred from their holding tanks, in groups of eight, to four 501 confinement tanks, a protocol widely used to elicit a stress response in fish (Pottinger \& Carrick 1999). After $2 \mathrm{~h}$ the fish were anaesthetized and blood samples were collected for cortisol analysis.

\section{Glucose and cortisol determinations}

Plasma glucose concentrations were measured using the glucose oxidase (Trinder) method (Sigma). Cortisol levels were determined in plasma by RIA (Pickering et al. 1987).

\section{Statistical analysis}

Data were analysed by ANOVA (Genstat 5; Lawes Agricultural Trust, Rothamsted Experimental Station, UK) with individual fish, tank, treatment (LPS/peptide or vehicle), DEX (DEX or vehicle) and time of sample as factors where appropriate. In all cases a plot of residuals against fitted values indicated that mean and variance were co-dependent. Therefore, data were log-transformed prior to analysis. Significant differences between groups were determined using the estimated standard error of the differences between means, derived from the ANOVA.

\section{Results}

Blood cortisol levels were significantly elevated at $8 \mathrm{~h}$ after injection with $\mathrm{rIL}-1 \beta$ at a dose of $0.6 \mathrm{nmol} / \mathrm{kg}$, relative to sham-injected controls (Fig. 1a; $P<0 \cdot 02$ ). Similarly, blood cortisol levels were also markedly increased $8 \mathrm{~h}$ after injection with LPS, relative to the PBS-injected control group (Fig. 2a; $P<0 \cdot 05$ ). In both cases, the stimulatory effects were no longer apparent at $24 \mathrm{~h}$ with plasma cortisol returning to basal levels by $72 \mathrm{~h}$, although preliminary data obtained from LPS/rIL- $1 \beta$ experiments conducted at a mean water temperature of $4.5{ }^{\circ} \mathrm{C}$ indicated a slower and more prolonged response with cortisol levels increasing $24 \mathrm{~h}$ after injection and persisting, in the case of LPS, for up to $48 \mathrm{~h}$ (data not shown). In contrast, the IL-1 $\beta$ peptides $\mathrm{P} 1$ and $\mathrm{P} 3$ did not appear to influence the release of plasma cortisol when administered alone or in combination (Fig. 2a). Plasma glucose levels were significantly higher at $8 \mathrm{~h}$ than at $0 \mathrm{~h}$ in every treatment group $(P<0 \cdot 001-P<0 \cdot 01$; Figs $1 \mathrm{~b}$ and $2 \mathrm{~b})$, although there were no significant differences between treatments and their respective vehicle controls at any time point. However, there was a tendency for plasma glucose levels at $8 \mathrm{~h}$ in all treatment groups exposed to the REB vehicle (Fig. 1b) to be higher than the other treatment groups at $8 \mathrm{~h}$ (Fig. 2b). This difference was evident when comparing plasma glucose levels in PBS-treated fish with those of REBtreated fish $(P<0 \cdot 05$; Figs $1 \mathrm{~b}$ and $2 \mathrm{~b})$.

Confirmation that the dose of DEX selected for these studies was appropriate was provided by the confinement experiment. Plasma cortisol levels were not elevated $(3 \cdot 2 \pm 1 \cdot 2 \mathrm{ng} / \mathrm{ml})$ in trout subjected to a confinement stressor after administration of DEX. However, plasma cortisol levels were elevated significantly following confinement $(60 \pm 8.9 \mathrm{ng} / \mathrm{ml})$ in fish receiving a vehicle injection only. With respect to rIL-1 $\beta$ and LPS, plasma cortisol levels were significantly and uniformly lower in fish receiving DEX compared with those that received DEX vehicle injection, at all sample times and for both LPS and rIL-1 $\beta$ treatment (Fig. 3a). In strong contrast, the administration of rIL-1 $\beta$ to DEX vehicle controls resulted in a significant elevation of plasma cortisol levels at 3,6 and $8 \mathrm{~h}$ post-injection. Similarly, the administration of LPS elevated plasma cortisol levels in DEX vehicle-treated fish between 3 and $6 \mathrm{~h}$ although, in this experiment, no significant difference between LPS treatment and its control was evident at $8 \mathrm{~h}$ (Fig. 3a). Plasma glucose levels 
$\mathbf{a}$
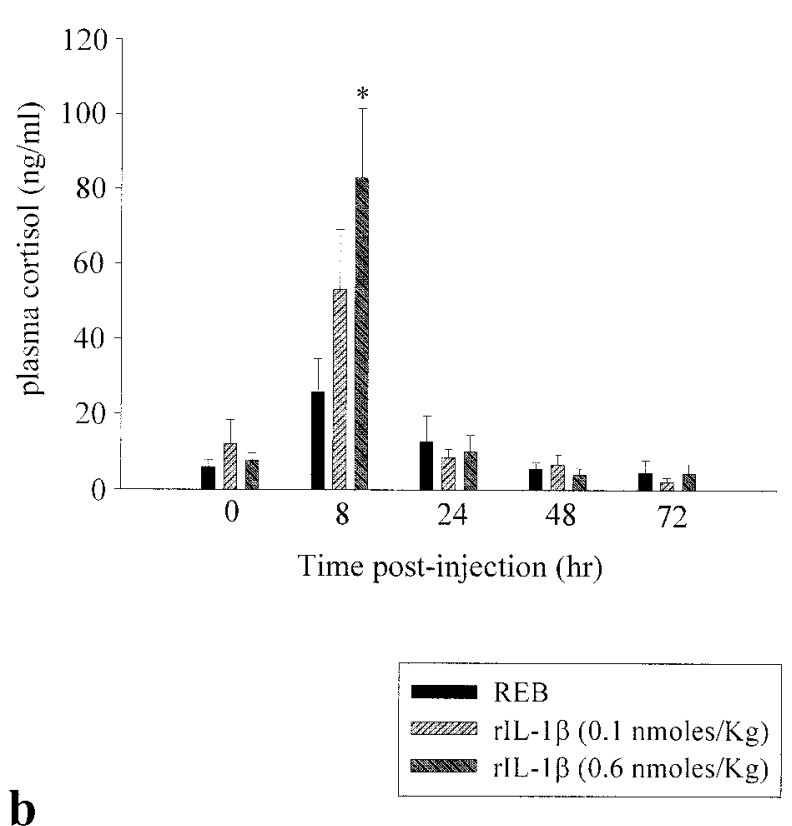

b

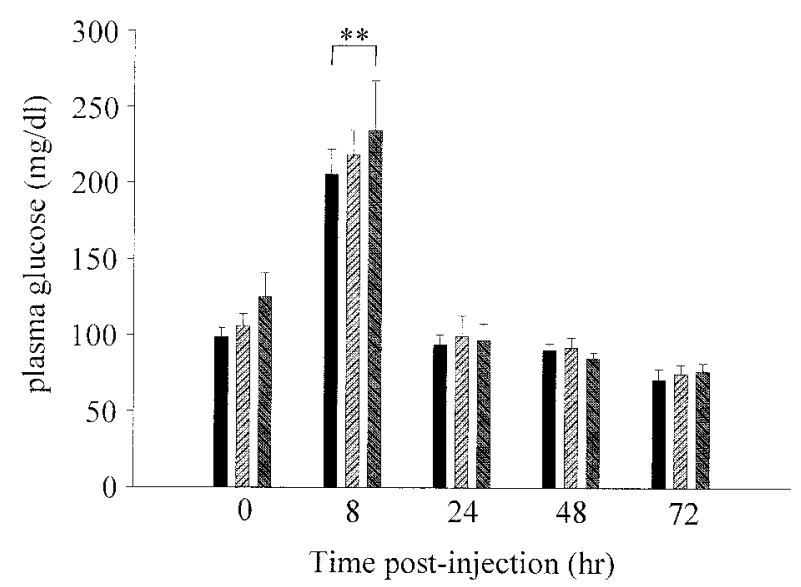

Figure 1 The time course of changes in (a) plasma cortisol and (b) plasma glucose occurring in fish receiving a $400 \mu$ i.p injection of either REB or rlL-1 $\beta(0 \cdot 1$ or $0 \cdot 6 \mathrm{nmol} / \mathrm{kg})$. Fish were sampled immediately before injection and at $8-72 \mathrm{~h}$ thereafter. Each data set is represented by means \pm S.E.M., $n=8$. Significant differences between the cortisol levels in REB and rIL-1 $\beta(0.6 \mathrm{nmol} / \mathrm{kg})$ at $8 \mathrm{~h}$ and between the glucose levels from 0 to $8 \mathrm{~h}$ are denoted by ${ }^{*} P<0 \cdot 02$ and ${ }^{*} P<0 \cdot 001$ respectively.

in DEX- or DEX vehicle-treated fish showed no treatment-related alterations (Fig. 3b). However, overall, plasma glucose levels were significantly higher in DEXtreated fish than in DEX vehicle-treated fish $(P<0 \cdot 001)$.

\section{Discussion}

Until now, with respect to cytokines, the examination of immune-neuroendocrine interactions in fish has been a
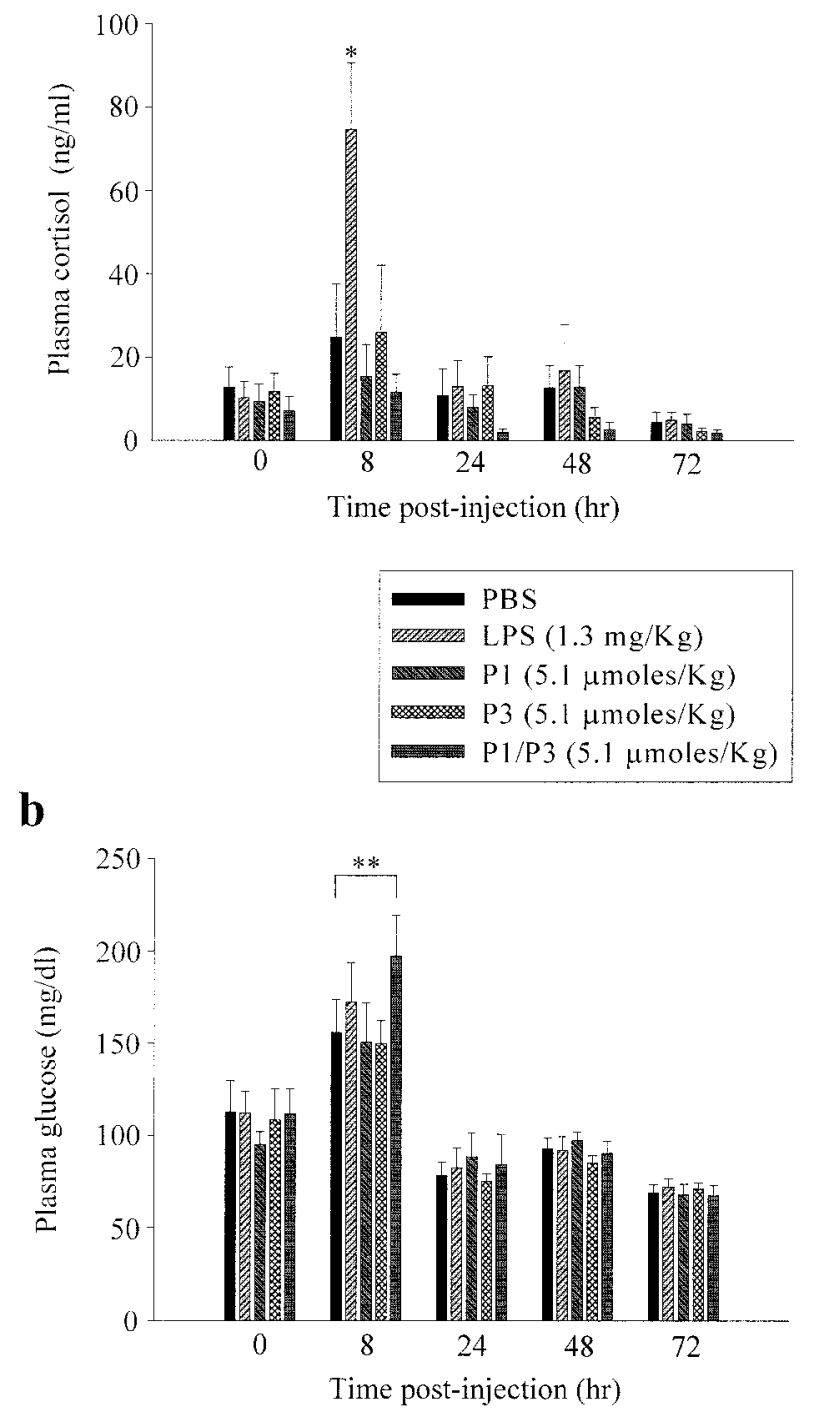

Figure 2 The time course of changes in (a) plasma cortisol and (b) plasma glucose occurring in fish receiving a $400 \mu \mathrm{l}$ i.p injection of PBS, LPS $(1 \cdot 3 \mathrm{mg} / \mathrm{kg}), \mathrm{P} 1(5 \cdot 1 \mu \mathrm{mol} / \mathrm{kg}), \mathrm{P} 3(5 \cdot 1 \mu \mathrm{mol} / \mathrm{kg})$ or P1/P3 $(5 \cdot 1 \mu \mathrm{mol} / \mathrm{kg})$. Fish were sampled immediately before injection and at $8-72 \mathrm{~h}$ thereafter. Each data set is represented by means \pm S.E.M., $n=8$. Significant differences between the cortisol levels in PBS- and LPS-injected fish at $8 \mathrm{~h}$ and between the glucose levels from 0 to $8 \mathrm{~h}$ are denoted by ${ }^{*} P<0.05$ and ${ }^{* *} P<0 \cdot 01$ respectively.

limited to the use of mammalian recombinant cytokines and cytokine antibodies (Balm et al. 1995, Ottaviani et al. 1995, Balm 1997). However, due to differences in sequence homologies, mammalian cytokine reagents may not necessarily behave in the same way (if at all) as the corresponding fish molecules, a premise exemplified by the absence of a cortisol response to murine IL-1 in tilapia (Balm et al. 1995, Balm 1997). Following the recent 


\section{a}
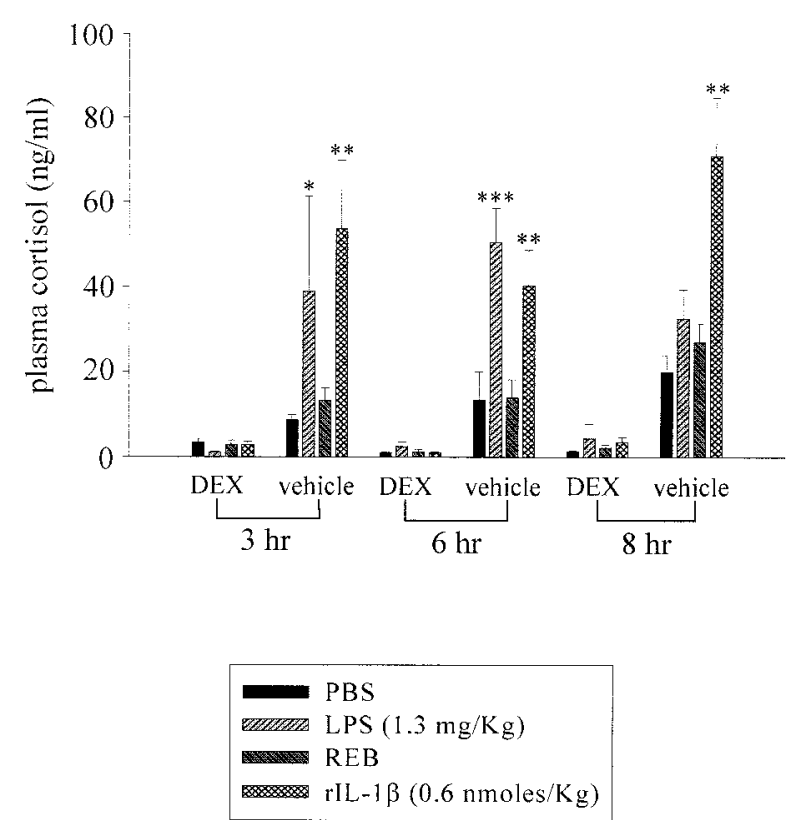

b

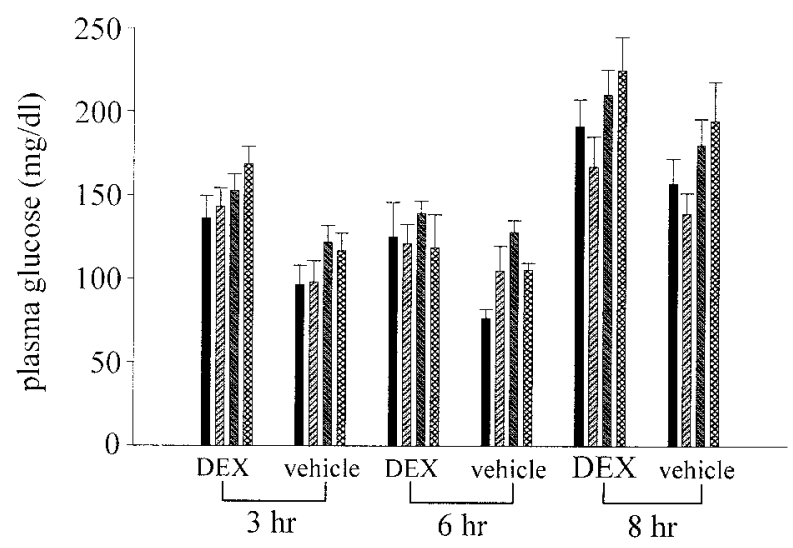

Figure 3 The time course of changes in (a) plasma cortisol and (b) plasma glucose occurring in fish receiving a $400 \mu$ i.p injection of PBS, LPS $(1 \cdot 3 \mathrm{mg} / \mathrm{kg})$, REB or rlL-1 $\beta(0.6 \mathrm{nmol} / \mathrm{kg})$. Half of each treatment group was injected $24 \mathrm{~h}$ previously with either DEX $(1 \mathrm{mg} / \mathrm{kg}$ in PBS:ethanol, $3: 1 ; 150 \mu \mathrm{l})$ or vehicle only. Fish were sampled 3-8 $\mathrm{h}$ after treatment injection. Each data set is represented by means \pm S.E.M., $n=8$. Significant differences between experimental and respective control groups at each time point are denoted by ${ }^{*} P<0 \cdot 05,{ }^{* *} P<0 \cdot 01$ and ${ }^{* * *} P<0 \cdot 001$.

cloning of the trout IL-1 $\beta$ gene and production of its recombinant protein, the present study, for the first time in fish, provides data that directly implicate IL-1 $\beta$ in the activation of the HPI stress axis. In addition to cytokines, bacterial endotoxins have been shown to indirectly elicit HPA activation through the systemic release of proinflammatory cytokines, including IL-1 $\beta$, IL-6 and tumour necrosis factor- $\alpha$.

In fish research, LPS has been shown previously to activate the HPI axis in vivo through the detection of elevated plasma cortisol levels (Balm 1997). These observations, along with studies demonstrating the LPSinducibility of the trout IL- $1 \beta$ gene, highlight the suitability of LPS as a positive control molecule in the present study (Zou et al. 2000). The i.p. injection of either IL-1 $\beta$ or LPS, at concentrations known to induce immunostimulatory effects in vivo (Hong 2002, Peddie 2002), evoked a rapid dose- and/or time-dependent stimulation of plasma cortisol levels, thus clearly implicating both molecules in the activation of the HPI axis. Furthermore, in terms of the time scale of the cortisol response to each treatment, the results are comparable with those of previous mammalian studies (Turnbull \& Rivier 1999). However, fish are known to be relatively insensitive to LPS treatment, with concentrations required to stimulate immune and HPI responses greatly exceeding those required in mammalian models (Zou et al. 2000).

In addition to cortisol, a second widely used index of stress in fish has been the measurement of plasma glucose concentration (Pottinger \& Carrick 1999). A wide range of stressors stimulate the sympathetic nervous system, leading to a rapid elevation of plasma glucose levels by a process mediated mainly by the glycogenolytic properties of circulating catecholamines (Wendelaar-Bonga 1997). Therefore, in light of the impact of rIL-1 $\beta$ and LPS on cortisol levels, the effects (if any) of treatment on the concentration of plasma glucose were also investigated. Under the conditions employed in this study, there was no evidence of treatment-specific elevations in glucose levels normally associated with more general stress responses or any indication of hypoglycaemia as reported in similar murine studies (Rey \& Besedovsky 1987). In support of these findings, subsequent mammalian studies have demonstrated that the peripheral administration of rIL-1 $\beta$ may have no or only modest effects on the systemic release of catecholamines and hence on plasma glucose levels (Rivier et al. 1989). However, glucose levels were enhanced in all samples taken $8 \mathrm{~h}$ after treatment injection. Even though a stealth approach was taken to anaesthetizing fish prior to handling and injection, the catecholaminergic response is notoriously sensitive to disturbance and a release of catecholamines associated with anaesthetization, capture and handling may well account for the observed glucose increases. Furthermore, with respect to the DEX blockade, the potential gluconeogenic properties of DEX may account for the overall increase in glucose levels associated with DEX treatment relative to DEX vehicle controls.

To complement studies using the whole IL-1 $\beta$ molecule, the neuroendocrine activity of two synthetic IL-1 $\beta$ peptides (PI and P3) was also examined. The 
first peptide, P1, corresponds to fragment 146-157 (YVTPVPIETEAR) of the trout sequence that is equivalent to the fragment 163-171 (VQGEESNDK) of the human IL-1 $\beta$ sequence, known to be part of the receptorbinding domain (Antoni et al. 1986). The peptide P3 was synthesized to complex with an adjacent region of the IL-1 receptor, equivalent to fragment 207-216 (YRRNTGVDIS) of the trout sequence (Peddie et al. 2001). In humans, the 163-171 fragment induces a range of immunostimulatory events, although without the pyrogenicity and inflammatory effects normally associated with the whole molecule (Antoni et al. 1986). For the present study, an appropriate dose of $\mathrm{P} 1$ and $\mathrm{P} 3$ was provided by recent in vivo studies whereby $\mathrm{P} 3$ was shown to possess a range of immunostimulatory activities in trout (Hong 2002, Peddie 2002). Interestingly, however, at an equivalent dose no elevations in cortisol or glucose were observed following the injection of $\mathrm{P} 3$ alone or in combination with $\mathrm{P} 1$. In the context of using the whole rIL-1 $\beta$ molecule to enhance the efficacy of fish vaccines, marked elevations in plasma cortisol may prove to be detrimental to the subsequent immune response. If following further research P3 is found to have no significant influence over CNS responses in trout, it may prove to be of value as an immune adjuvant in future fish vaccine development, as seen in mammals with respect to the 163-171 fragment of human IL-1 $\beta$ (Beckers et al. 1993).

In mammals, it is generally accepted that the primary site of action of peripherally administered $\mathrm{rIL}-1 \beta$ is the hypothalamus. A direct effect of rIL-1 $\beta$ on pituitary and adrenal tissues is believed to be too slow in onset to account for the rapid hormonal effects of this cytokine in vivo (Turnbull \& Rivier 1999). Cytokine activation of the HPA axis is subject to feedback control exerted by circulating glucocorticoids. In this respect, the cortisol agonist DEX has been shown to specifically inhibit the IL-1 $\beta$-stimulated release of hypothalamic $\mathrm{CRH}$ and, hence, the subsequent secretion of ACTH and glucocorticoids (Loxley et al. 1993). In fish, DEX binds to specific corticosteroid receptors within brain tissues, including the hypothalamus (Allison \& Omeljaniuk 1998). Subsequent studies have used DEX to block endogenous ACTH release without suppressing the cortisol-releasing capacity of the interrenal tissue (Pottinger \& Carrick 2001). Therefore, DEX pretreatment was incorporated into the current study to further investigate the interaction of rIL-1 $\beta$ and LPS with elements of the HPI axis. Consistent with mammalian studies, DEX completely eliminated the cortisol response to both rIL-1 $\beta$ and LPS, thus supporting the premise that in fish IL-1 $\beta$ and LPS affect plasma cortisol levels via interaction at the level of the hypothalamic-pituitary axis. Although the precise mechanisms of IL-1 $\beta$ intervention within the CNS remain to be elucidated, the observed expression of a recently cloned trout IL-1 receptor type I-like gene in brain and pituitary cDNA samples provides further support for a hypothalamic-pituitary site of action (JW Holland, unpublished observations).

Overall, the demonstration of the HPI-stimulatory activity of trout rIL-1 $\beta$ in the present study, along with the future provision of other recombinant pro-inflammatory cytokines, will no doubt fuel research in the area of immune-neuroendocrine communication in fish.

\section{Acknowledgements}

This work was supported by a grant from NERC, UK (GR3/11695) and was performed under appropriate Home Office Project and Personal licences. Many thanks go to $\mathrm{Mr}$ Toby $\mathrm{R}$ Carrick (Centre for Ecology and Hydrology, Windermere) for his technical assistance throughout this study. There is no conflict of interest that would prejudice the impartiality of this manuscript.

\section{References}

Allison CM \& Omeljaniuk RJ 1998 Specific binding sites for $\left[{ }^{3} \mathrm{H}\right]$ dexamethasone in the hypothalamus of juvenile rainbow trout, Oncorhynchus mykiss. General and Comparative Endocrinology 110 $2-10$.

Antoni G, Presentinin R, Perin F, Tagliabue A, Ghiara P, Censini S, Volpini G, Villa L \& Boraschi D 1986 A short synthetic peptide fragment of human interleukin 1 with immunostimulatory but not inflammatory activity. Journal of Immunology 137 3201-3204.

Balm PHM 1997 Immune-endocrine interactions. In Fish Stress and Health in Aquaculture, pp 195-221. Eds GK Iwama, AD Pickering, JP Sumpter \& CB Schreck. Cambridge: Cambridge University Press.

Balm PHM, van Lieshout E, Lokate J \& Wendelaar-Bonga SE 1995 Bacterial lipopolysaccharide (LPS) and interleukin 1 (IL-1) exert multiple physiological effects in the tilapia Oreochromis mossambicus (Teleostei). Journal of Comparative Physiology B 165 85-92.

Beckers W, Villa L, Gonfloni S, Castagnoli L, Newton SMC, Cesareni G \& Ghiari P 1993 Increasing the immunogenicity of protein antigens through the genetic insertion of VQGEESNDK sequences of human IL-1 $\beta$ into their sequence. Journal of Immunology $\mathbf{1 5 1}$ $1757-1764$.

Bird S, Wang T, Zou J, Cunningham C \& Secombes CJ 2002 The first cytokine sequence within cartilaginous fish: IL-1 $\beta$ in the small spotted catshark (Scyliorhinus canicula). Journal of Immunology 168 3329-3340.

Bradford MM 1976 A rapid and sensitive method for the quantification of microgram quantities of protein utilizing the principle of protein-dye binding. Analytical Biochemistry 72 248-254.

Buckingham JC, Loxley HD, Taylor AD \& Flower RJ 1994 Cytokines, glucocorticoids and neuroendocrine function. Pharmacological Research 30 35-42.

Buckingham JC, Loxley HD, Christian HC \& Philip JG 1996 Activation of the HPA axis by immune insults: roles and interactions of cytokines, eicosanoids, and glucocorticoids. Pharmacology, Biochemistry and Behavior 54 285-298.

Fujiki K, Shin D, Nakoa M \& Yano T 2000 Molecular cloning and expression analysis of carp (Cyprinus carpio) interleukin-1 $\beta$, high affinity immunoglobulin E Fc receptor $\gamma$ subunit and serum amyloid A. Fish and Shellfish Immunology 10 229-242.

Hong S 2002 Bioactivity of recombinant IL-1 $\beta$ and derived peptides, and analysis of IL-1 $\beta$ processing in rainbow trout, Oncorhynchus mykiss. PhD Thesis. University of Aberdeen. 
Hong S, Zou J, Crampe M, Peddie S, Scapigliati G, Bols N, Cunningham C \& Secombes CJ 2001 The production and bioactivity of rainbow trout (Oncorhynchus mykiss) recombinant IL-1ß. Veterinary Immunology and Immunopathology 81 1-14.

Loxley HD, Cowell A-M, Flower RJ \& Buckingham JC 1993 Modulation of the hypothalamo-pituitary-adrenocorticol responses to cytokines in the rat by lipocortin 1 and glucocorticoids: a role for lipocortin 1 in the feedback inhibition of CRF-41 release? Neuroendocrinology 57 801-814.

Ottaviani E, Caselgrandi E \& Franceschi C 1995 Cytokines and evolution: in vitro effects of IL-1 alpha, IL-1 beta, TNF alpha and TNF beta on the ancestral type of stress response. Biochemical and Biophysical Research Communications 207 288-292.

Peddie S 2002 The effects of novel immunostimulants on immunity and disease resistance in the rainbow trout, Oncorhynchus mykiss. PhD Thesis. University of Aberdeen.

Peddie S, Zou J, Cunningham C \& Secombes CJ 2001 Rainbow trout (Oncorhynchus mykiss) recombinant IL-1 $\beta$ and derived peptides induce migration of head-kidney leucocytes in vitro. Fish and Shellfish Immunology 11 697-709.

Peddie S, Zou J \& Secombes CJ 2002 A biologically active IL-1 $\beta$ derived peptide stimulates phagocytosis and bactericidal activity in rainbow trout, Oncorhynchus mykiss (Walbaum) head kidney leucocytes in vitro. Journal of Fish Diseases 25 1-10.

Pickering AD, Pottinger TG \& Sumpter JP 1987 On the use of dexamethasone to block the pituitary-interrenal axis in the brown trout, Salmo trutta L. General and Comparative Endocrinology 65 $346-353$

Pottinger TG \& Carrick TR 1999 A comparison of plasma glucose and plasma cortisol as selection markers for high and low stressresponsiveness in female rainbow trout. Aquaculture 175 351-363.

Pottinger TG \& Carrick TR 2001 ACTH does not mediate divergent stress responsiveness in rainbow trout. Comparative Biochemistry and Physiology A 129 399-404.

Rey AD \& Besedovsky H 1987 Interleukin 1 affects glucose homeostasis. American Journal of Physiology 253 R794-R798.

Rivier CL, Vale CW \& Brown M 1989 In the rat, interleukin-1 $\alpha$ and $-\beta$ stimulate adrenocorticotropin and catecholamine release. Endocrinology 125 3090-3102.
Sapolsky RM, Romero M \& Munck AU 2000 How do glucocorticoids influence stress responses? Integrating permissive, suppressive, stimulatory, and preparative actions. Endocrine Reviews $2155-89$.

Secombes CJ, Zou J, Daniels G, Cunningham C, Koussounadis A \& Kemp G 1998 Rainbow trout cytokine and cytokine receptor genes. Immunological Reviews 166 333-340.

Secombes CJ, Wang T, Hong S, Peddie S, Crampe M, Laing KJ, Cunningham C \& Zou J 2001 Cytokines and innate immunity in fish. Developmental and Comparative Immunology 25 713-723.

Shintani F, Nakaki T, Kanba S, Kato R \& Asai M 1995 Role of interleukin-1 in stress responses. Molecular Neurobiology 10 47-71.

Turnbull AV \& Rivier CL 1999 Regulation of the hypothalamicpituitary-adrenal axis by cytokines: actions and mechanisms of action. Physiological Reviews 79 1-71.

Wendelaar-Bonga SE 1997 The stress response in fish. Physiological Reviews 77 591-625.

Weyts FAA, Cohen N, Flik G \& Verburg van Kemenade BML 1999 Interactions between the immune system and the hypothalamo-pituitary-interrenal axis in fish. Fish and Shellfish Immunology 9 1-20.

Zou J, Grabowski PS, Cunningham C \& Secombes CJ 1999a Molecular cloning of interleukin-1 $\beta$ from rainbow trout Oncorhynchus mykiss reveals no evidence of an ICE cut site. Cytokine 11 552-560.

Zou J, Cunningham C \& Secombes CJ 19996 The rainbow trout Oncorhynchus mykiss interleukin- $1 \beta$ gene has a different organization to mammals and undergoes incomplete splicing. European Journal of Biochemistry 259 901-908.

Zou J, Holland J, Pleguezuelos O, Cunningham C \& Secombes CJ 2000 Factors influencing the expression of interleukin- $1 \beta$ in cultured rainbow trout (Oncorhynchus mykiss) leucocytes. Developmental and Comparative Immunology 24 575-582.

Received 15 April 2002

Accepted 12 June 2002 